\title{
PARMÉNIDE CHEZ LUCRÈCE
}

\author{
PAul Jackson \\ Open University, UK
}

Resumo. Estudos recentes sobre o alinhamento de Lucrécio com a tradição da poesia filosófica tendem a dar destaque à figura de Empédocles. Sem dúvida sua obra era familiar a Lucrécio, que tanto elogia quanto critica o poeta-filósofo nominalmente no primeiro livro do De rerum natura; mas Lucrécio não é o único. Filodemo, em seu Sobre a piedade, menciona o polêmico tratado epicurista Contra Empédocles, e Diógenes Laércio atesta que o próprio Epicuro teria escrito especificamente a respeito de Empédocles. A inscrição de Diógenes de Oinoanda também menciona Empédocles. Se a influência de Empédocles sobre Lucrécio (Campbell, Furley), e especialmente sobre o proêmio do $D R N$ (Sedley), tem sido sugerida e efetivamente aceita, aquela de outro poeta-filósofo merece um exame mais aprofundado. A influência de Parmênides sobre Lucrécio foi relativamente negligenciada e, no meu entender, subestimada. O artigo de Rumpf na Philologus, "Lukrez und Parmenides" (1995), aponta a influência de Parmênides nos dois primeiros livros do DRN. Já Gale (1994) propõe que qualquer influência é indireta. Embora Lucrécio não mencione Parmênides no $D R N$, existem ecos intertextuais

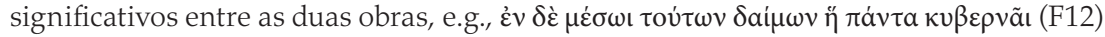
de Parmênides podendo corresponder a quae...rerum naturam sola gubernas (DRN 1.21) or solis cursus lunaeque meatus...flectat natura gubernans (DRN 5.76-7). Este artigo vai rastrear alguns desses paralelos para ir mais longe do que Rumpf, ao argumentar pela influência de Permênides sobre o DRN como um todo, tanto no que respeita ao modo de expressão de Lucrécio quanto no que respeita ao conteúdo mesmo do $D R N$ e à física epicurista que ele transmite. Assim, ficará demonstrado que realmente existe um Parmênides em Lucrécio, bem como poderá ensejar uma maior elucidação de Parmênides.

Palavras-chave. Lucrécio, Parmênides, poeta-filósofo, influência, intertextualidade.

This paper takes its title from Henri Patin's “L'Anti-Lucrèce Chez Lucrèce", the seventh chapter in his Études sur la poésie latine. According to Minadeo (1969: 19), Patin here represents Lucretius as being "in dubious conflict with Epicurean theological principles".

The influence of Epicurus upon Lucretius has however been demonstrated elsewhere, with Sedley (1998: 102) referring to Lucretius as a fundamentalist - that, whereas other Epicurean philosophers had developed

•Artigo recebido em 29.jan.2014 e aceito para publicação em 7.jul.2014. 
Epicurus' philosophy in the two hundred years since his death, Lucretius remained true.

Yet Sedley (1998: 11) confesses that "Lucretius is thus, in West's terminology, a practitioner of the 'multi-correspondence simile."' Multi-correspondences suggest multiple influences.

The influence of Empedocles upon Lucretius has been contentious. Sedley (1998: 34) claims that "Lucretius is the servant of two masters. Epicurus is the founder of his philosophy; Empedocles is the father of his genre." Whereas Furley (1989: 178) claims that "the Epicureans were certainly followers of Empedocles" philosophically. Although Sedley and Furley differ as to the extent of Empedocles' influence upon Lucretius, with Sedley (1998: 18) insisting that "it seems certain that Empedocles was not regarded by Epicurus or his successors as any sort of philosophical forerunner," they both acknowledge and recognise an influence.

But the influence of Parmenides upon Lucretius has been largely ignored. This is despite Gale (1994: 51-9) writing that "Lucretius' models were accordingly much earlier writers, the philosopher-poets of the sixth and fifth centuries B.C., especially Empedocles of Acragas and his predecessor Parmenides." Waszink (1954: 253) writes that "it seems not unlikely that Lucretius was acquainted with at least the beginning of the poem of Parmenides, Empedocles' master, and was impressed by Parmenides' identification of Light and Truth". ${ }^{1}$ Gale (1994: 51-9) does conclude however that "on the whole, any influence seems more likely to be indirect: much may have come to Lucretius through Empedocles, with whose writings he was unquestionably familiar".2

Sedley (1998: 23) thinks that "there can be little doubt that it was to Empedocles, rather than to the only other available candidate, Parmenides, that Lucretius looked as his great Greek forebear in the tradition of cosmological poetry. This was certainly the comparison that regularly occurred to Roman readers." Here Sedley cites Quintilian:

[1] while among the Greeks we have Empedocles and among our own poets Varro and Lucretius. ${ }^{3}$

${ }^{1}$ In Rumpf (2005: 78).

2 "Theophrastus affirms that he [Empedocles] was an admirer of Parmenides and imitated him in his verses, for Parmenides too had published his treatise on nature in verse," "ó $\delta \grave{\varepsilon} \Theta \varepsilon \dot{c o p} \varphi a \sigma \tau o \varsigma$

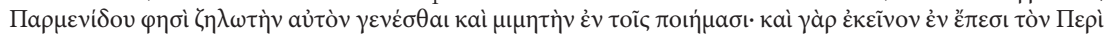

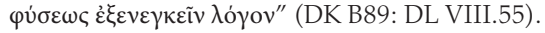

3 "tum vel propter Empedoclea in Graecis, Varronem ac Lucretium in Latinis" (Quintilian, Institutio Oratoria, I.4.4; DK A24). 
and Lactantius:

[2] Empedocles, whom one would be uncertain whether to count as a poet or philosopher, since he wrote about nature in verse, as Lucretius and Varro did among the Romans. ${ }^{4}$

Rumpf's article "Lukrez und Parmenides" challenges this. Here Rumpf (2005: 94) suggests that "the influence of Parmenides in Lucretius' books one and two is far more decisive than has usually been acknowledged, and that regardless of the diametrical opposition of the philosophical systems, ${ }^{5}$ Lucretius consciously referred to and played with Parmenides' text." Rumpf (2005: 78) indeed reveals a "full series of parallels with the teaching of Parmenides' philosophy of being",' despite (2005: 78) citing Henderson who wrote "I can point to nothing in De rerum natura that definitely shows colour Parmenideus."

Indeed, Rumpf argues (2005: 79) that "Lucretius has taken direct inspiration from passages of Parmenides' poems in a whole series of other occasions, and in both the first two books of De rerum natura, one can recognise a continuous 'Parmenides thread', in spite of the fundamental difference of their philosophical systems". ${ }^{\prime 7}$ Yet Rumpf concludes (2005: 92) that "the quest for parallels with Parmenides is certainly not yet completed here", ${ }^{\prime}$ and it is indeed this quest that is continued in this paper.

Gale (1994: 51-9), though insisting that "it is difficult to find examples of Parmenidean influence," does concede that there is one "striking example." Parmenides writes that

[3] in the midst of these is the goddess who steers all things; for she rules over hateful birth and union of all things. ${ }^{9}$

and Lucretius in his DRN writes

\footnotetext{
${ }_{4}$ "Empedocles, quem nescias utrumne inter poetas an inter philosophos numeres, quia de rerum natura versibus scripsit ut apud Romanos Lucretius et Varro" (Lactantius, Institutiones Divinae II.12.4; DK A24).

${ }^{5}$ Parmenides denied the existence of void, whereas the Epicureans considered everything to be atom and void.

${ }_{6}$ "Hier soll eingehender gezeigt werden, daß es eine ganze Reihe solcher Parallelen auch zu Parmenides' seinsphilosophischem Lehrgedicht gibt." Rumpf compares the two proems; "nothing from nothing;' and 'the world of the appearances.'

7 "Wie hier gezeigt werden soll, hat Lukrez an einer ganzen Reihe weiterer Stellen auf Passagen aus Parmenides' Gedicht zurückgegriffen und läßt sich in den ersten beiden Büchern von De rerum natura ungeachtet der fundamentalen Verschiedenheit der philosophischen Systeme geradezu eine durchgängige, Parmenideslinie' erkennen."

8 "Die Suche nach Parallelen zu Parmenides ist hier sicher noch nicht am Ende angelangt."

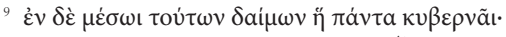

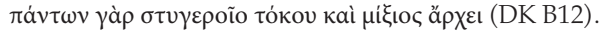


[4] since therefore you alone [Venus] govern the nature of things. ${ }^{10}$

The parallel is of course between the words $\kappa v \beta \varepsilon \rho v a \tilde{u}$ and gubernas, both in prominent positions at the ends of their lines.

Gale (1994: 51-9) however dismisses the parallel, arguing that "the image of god as helmsman is common in Greek and Latin literature".11 The example provided comes from Cicero's De natura deorum:

[5] if on the other hand some god resides within the world as its governor and pilot, maintaining the courses of the stars, the changes of the seasons and all the ordered processes of creation. ${ }^{12}$

Importantly, it ought to be mentioned that these are the words of Cicero's Epicurean interlocutor, Gaius Velleius.

Rumpf (2005: 79) claims conversely that it is this parallel "which takes the Lucretian Venus close to the Goddess in Parmenides".13

But it will be argued here that there is much more to this parallel than has previously been assumed.

The Lucretian Venus, as Smith (1975: 2-3) puts it, "is a figure of extraordinary complexity." The proem of DRN is seemingly an invocation of the Olympian goddess, with the first words being

[6] mother of Aeneas and his race, darling of men and gods, nurturing Venus. ${ }^{14}$

Lucretius thereafter refers to her as "goddess"15 and "divine one"; 16 and almost prays

[7] therefore all the more grant to my speech, goddess, an ever-living charm. ${ }^{17}$

This invocation, in such a prominent place, and the subsequent language seems inconsistent with Lucretius' position on religio, denying the existence of these gods. Indeed Clay (1983: 236) cites Polignac who "turned to his prayer to Venus to show that Lucretius has 'forgotten himself' in invoking the very gods he would destroy."

10 "Quae quoniam rerum naturam sola gubernas" (DRN I.21).

${ }^{11}$ Lewis (1996: 358) translate guberno as "to steer, pilot...to direct, manage, conduct, govern,

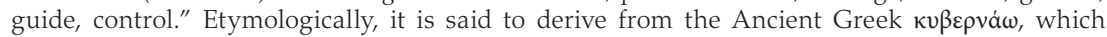
Liddell \& Scott (1997: 397) translate as "to steer...to hold the helm of the state, guide, govern."

12 "sive in [ipso] mundo deus inest aliquis qui regat, qui gubernet, qui cursus astrorum mutationes temporum rerum vicissitudines ordinesque conservet" (DND I.52).

${ }_{13}$ "die die Lukrezische Venus in die Nähe der Göttin des Parmenides bringt."

14 "Aeneadum genetrix, hominum divomque voluptas, / alma Venus" (DRN I.1-2).

15 "dea" (DRN I.6).

16 "diva" (DRN I.12).

17 "quo magis aeternum da dictis, diva, leporem" (DRN I.28). 
Rather, however, it again becomes clear that Lucretius is being insincere. Masson (1907: 262), citing Buchanan, argues that "this invocation is merely 'in the highest sense a parody.'” And Godwin (2004: 53) wittily dubs the proem a Venus fly-trap, with Lucretius exploiting the alluring goddess to entice the audience and lull it into a false sense of security. For beyond the proem Venus only fleetingly reappears, and is then merely representative of love..$^{18}$ In the 7,366 lines of hexameter verse beyond the proem, she only then appears on 33 other occasions; whereas natura, having appeared only three times in the proem, features on 149 occasions thereafter. Almost immediately after the proem, Lucretius writes

[8] from which nature makes all things and increases and nourishes them, and into which the same nature again reduces them when dissolved. ${ }^{19}$

And then in the fifth book of $D R N$, Lucretius writes that

[9] I will explain by what force pilot nature steers the courses of the sun and the goings of the moon ${ }^{20}$

with gubernans again at the end of the line. In DRN, the Venus of the proem quae gubernas, and Mars, have been appropriated by another gubernator, natura. ${ }^{21}$

There are several explanations for the inclusion of Venus in the proem. An invocation was customary in epic hexameter verse, Lucretius' choice of medium, and so he is respecting a literary precedent. Lucretius can then expect comparison with his predecessors in the genre, and indeed challenge them. ${ }^{22}$

Sedley (1998: 21ff) reasons that the proem acknowledges the influence of Empedocles upon Lucretius, with Venus and Mars corresponding

${ }^{18}$ DRN I.228; II.173; 437; III.776; IV.1037-1287; V.737; 848; 897; 962; 1017. Indeed the very mention of Veneres, Venuses (DRN IV.1185) is contrary to traditional mythology.

19 "unde omnis natura creet res auctet alatque / quove eadem rursum natura perempta resolvat" (DRN I.56-7).

20 "solis cursus lunaeque meatus / expediam qua vi flectat natura gubernans" (DRN V.76-7).

${ }^{21}$ Also "may pilot fortune steer this far from us," "quod procul a nobis flectat fortuna gubernans" (DRN V.107). The explanation for the occurrence of fortuna gubernans is a little more complex, but with a determinate natura determining through the deterministic foedera naturae the indeterminate swerve of the atom, then fortuna gubernans can be understood as natura gubernans. Compare Parmenides: "since it was just this that Fate did shackle / To be whole and changeless",

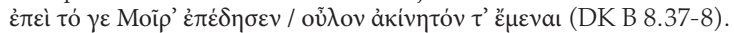

${ }^{22}$ Conventionally, epic poems opened with an invocation of a muse. For instance, "tell me, $\mathrm{O}$

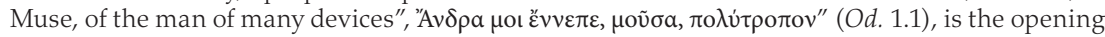
of the Odyssey. Therefore Lucretius is going beyond epic tradition. Masson (1907: 261) stresses that Lucretius, in framing his scientific treatise within the framework of a poem, is following the literary example set by his predecessors. 


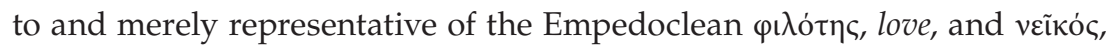
hate. $^{23}$

Methodologically, the proem is a philosophical strategy. Plato arranges his Symposium in such a way that various opinions about love are systematically offered, criticised, and rejected. Lucretius in DRN opens with the known and accepted gods of orthodoxy, who thereafter can then be criticised and rejected. It may also be that Lucretius wanted to initially engage his audience with the known and accepted, rather than immediately lose his audience without this. Once the audience was engaged, the delivery of Epicurean doctrine could be facilitated.

Structurally, Venus, as the goddess of love and therefore of attraction, sex, procreation, birth, creativity, and new life, is suitably placed at the beginning of DRN. The poem ends with the plague of Athens, which resulted in destruction, death, and decay. Therefore the opening and close of DRN reflect the cycle of life, and so Lucretius offers and presents an organised and ordered whole.

And Venus is the personification of the Epicurean summum bonum, pleasure (voluptas).

The Goddess in Parmenides is a mysterious figure too. Gallop (1984: 83) advises reading the previous reference [3] "in conjunction with the paraphrase of Aëtius", ${ }^{24}$ in which Aëtius writes that

[10] the midmost of the mixed bands is the <origin $>$ and $<$ cause $>^{25}$ of movement and coming-to-be for all of them, and it is this that he calls "the goddess who steers", "holder of the keys", 26 "Justice", and "Necessity". ${ }^{27}$

\section{Parmenides also writes}

[11] and for these Justice, much-avenging, holds the keys of retribution. ${ }^{28}$

[12] therefore neither [its] coming-to-be / Nor [its] perishing has Justice allowed, relaxing her shackles, / But she holds [it] fast. ${ }^{29}$

${ }^{23}$ F 17.

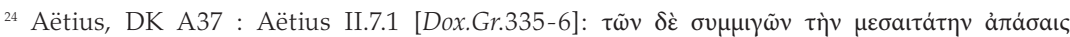

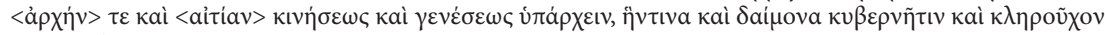

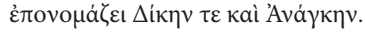

${ }^{25}$ Gallop (1984: 116): "the text is corrupt. The translation follows DK, supplying <ả $\rho \chi \eta \dot{v}>$ and $<$ aitiav>. Diels restored the text differently in Dox.Gr.

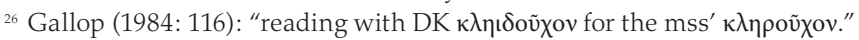

${ }^{27}$ Furley (1989: 28) doesn't accept that the goddess is Justice, as "she refers in line 28 to $\theta \dot{\varepsilon} \mu \varsigma \varsigma \tau$

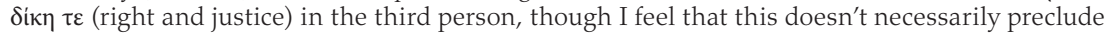
her from talking about herself, or an aspect of herself.

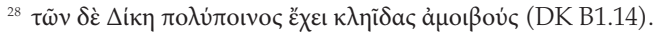

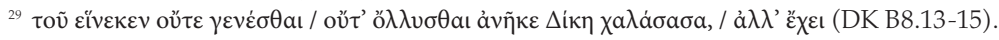


[13] for strong Necessity / Holds [it] fast in the chains of a limit, which fences it about. ${ }^{30}$

[14] whence it grew and how Necessity did guide and shackle it / To hold the limit of the stars. ${ }^{31}$

And furthermore, Gallop (1984: 89) understands this goddess as being the subject of the following fragments:

[15] <she placed > young males on the right side [of the womb], young females on the left. ${ }^{32}$

[16] she devised Love first of all the gods. ${ }^{33}$

According to Aëtius at least, the Goddess in Parmenides is the holder of the keys; Justice; and Necessity. Or rather, the holder of the keys; Justice; and Necessity have appropriated the Goddess. $\Delta i \kappa \eta$ and Ava $\gamma \kappa \eta$ are feminine, as are á $\rho \chi \eta \dot{~ a n d ~ a i t i ́ a, ~ i n ~ m u c h ~ t h e ~ s a m e ~ w a y ~ a s ~ n a t u r a ~ a l s o ~ r e t a i n s ~ t h a t ~}$

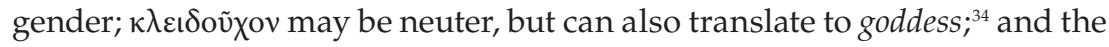
adjective $\mu \varepsilon \sigma a i \tau a \tau o \varsigma$ is here in the feminine.

Tarán (1965: 31) writes that "the fact that the goddess remains anonymous shows that she represents no religious figure at all and only stands as a literary device implying that the 'revelation' is the truth discovered by Parmenides himself. Parmenides could not have attributed any reality to the goddess because for him there existed only one thing, the unique and homogeneous being." And Mourelatos (1970: 44) writes that "at every turn, the story of the Kouros' encounter with the divine- the Heliades, Dike, the goddess- lacks any hint of worship."

The parallel between Lucretius and Parmenides is not only this, that the goddesses in the poems of each are actually not religious figures, but also that they are both representative of the natural, scientific process. ${ }^{35} \mathrm{In}$ deed Rumpf (2005: 81) writes that "a parallel exists in that a personified

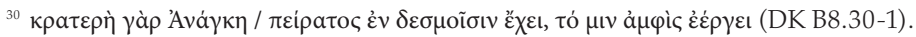

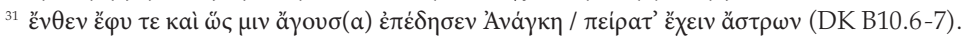

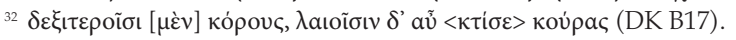

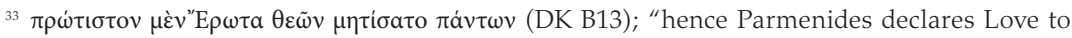

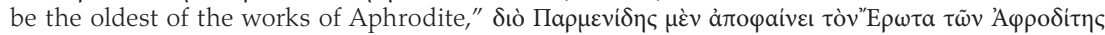
है $\rho \omega \nu \pi \rho \varepsilon \sigma \beta \dot{\tau} \tau \alpha \tau o v$ (Plutarch, Amatorius 756f); and "and he says that she [the goddess] is also the

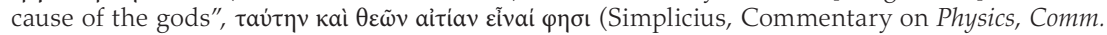
Arist. Gr. IX,39).

${ }^{34}$ Liddell \& Scott 1997: 379.

${ }^{35}$ Represented by Mars in the proem: "Mars mighty in battle," "Mavors / armipotens" (DRN I.32-3). Indeed, Mars is only mentioned on one more occasion in DRN: "were taught by the Carthaginians to endure the wounds of war, and to confound the great hosts of Mars," "belli docuerunt volnera Poeni / suffere et magnas Martis turbare catervas" (DRN V.1303-4), where Mars is merely a metaphor for war. 
female being, indicated with Avá $\gamma \kappa \eta$ (DK 28 B 10,6) and natura (56 and 57), takes the role of natural events". ${ }^{36}$ So this is as much a philosophical parallel as a literary one.

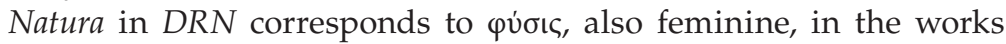
of Epicurus. Therefore Parmenides influences Lucretius philosophically through Epicurus, bearing in mind Sedley, of Lucretius being a fundamentalist. But Lucretius is more explicit about the Parmenidean influence. To what extent, though, can this philosophical influence be understood?

Despite the fundamental difference of their philosophical systems, Parmenides more specifically influenced Epicureanism over the immortality and unchanging nature of atoms, looking back to [12]; the governance of natura, comparing [8] to [3] and also [10-16]; and limitations in nature, comparing [13-14] to "nature had provided a limit", ${ }^{37}$ and "by fixed law of nature ${ }^{\prime \prime 38}$ in $D R N$.

On a literary level, Gallop (1984: 5-7) claims that DK B1 is the proem of Parmenides' On nature, a proem which the Goddess dominates, with Parmenides writing

[17] when they brought and placed me upon the much-speaking route of the goddess. ${ }^{39}$

[18] the goddess received me kindly. ${ }^{40}$

This Goddess then promises to impart the true nature of things to him, which she does from DK B2 onwards. It is notable that beyond the proem, she is then referred to as the holder of the keys; Justice; and Necessity, aside from [3], which is in the $\Delta \dot{o} \xi \alpha$. In much the same way in DRN, Venus dominates the proem, and natura beyond, with instances of Venus beyond being merely representative of love. Therefore Parmenides directly influences the structure of not only Lucretius' proem, as Rumpf (2005: 79-83) suggests, which in itself adds another layer of complexity to an already complex proem to $D R N$, but indeed influences the whole of $D R N$.

If indeed this influence does exist, it must be asked why Parmenides is not named in DRN, when Heraclitus, Empedocles, and Anaxagoras are. For Gale writes (1994: 51-9) that "there is no direct evidence that Lucretius was actually familiar with Parmenides' poem. Unlike Democritus and Em-

\footnotetext{
36 "Eine Parallele besteht zudem darin, daß mit 'Avá $\gamma \kappa \eta$ (DK 28 B 10, 6) bzw. natura (56 und 57) jeweils eine personifizierte feminine Instanz als Subjekt der Naturvorgänge fungiert."

37 "finem natura parasset" (DRN I.551).

38 "foedere naturae certo" (DRN V.924)."

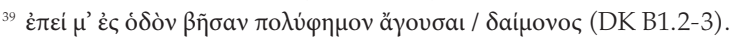

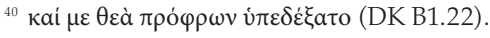


pedocles, he is not specifically mentioned in the DRN." For instance, Sedley (1998: 11) refers to the "paean of praise" for Empedocles:

[19] foremost among whom is Empedocles of Acragas. ${ }^{41}$

Gale (1994: 51-9) writes that "Simplicius' remarks on the scarcity of manuscripts of Parmenides' poem (admittedly several centuries later) perhaps tell against a direct acquaintance." The admission however is important. Rumpf (2005: 78) argues that "the fact that Parmenides was known in the Roman Epicurean circles is proved by the critic of Velleius in Cic. Nat. Deor. $1,11^{\prime \prime}{ }^{42}$

And Gale (1994: 51-9) actually cites Henderson, who "notes that Parmenides' views were criticized in 'the traditional Epicurean review of earlier philosophers', and this, or his admiration for Empedocles, might have led Lucretius to read Parmenides himself," and making a comparison between the poems of Parmenides and Lucretius, Gale acknowledges the epic motifs in each, with Homeric, Hesiodic and Ennian influences, as well as the light and darkness symbolism ${ }^{43}$ and travel imagery.

And so Rumpf (2005: 95) writes that Parmenides "pays homage to the founder of philosophical didactic poetry by way of constant innuendo while avoiding the difficult task of discussing the philosophy of Being, which would also have made inevitable a devastating critique."

\footnotetext{
41 "quorum Acragantinus cum primis Empedocles est" (DRN I.716).

${ }_{42}$ "Daß Parmenides in römischen Epikureerkreisen jedenfalls bekannt war, zeight die Kritik des Velleius in Cic. nat.deor.1,11."

${ }^{43}$ Gale (1994: 58) writes that "light and darkness in the DRN often symbolize the contrast between the saving philosophy of Epicurus and the ignorance and consequent fears of the majority of the human race, especially in the proems" (also DRN II.15: "in what gloom of life," "qualibus in tenebris vitae;" III.1-2: "o you who first amid so great a darkness were able to raise aloft a light so clear, illuminating the blessings of life," "o tenebris tantis tam clarum extollere lumen / qui primus potuisti inlustrans commoda vitae;" IV.8, I.933: "next because the subject is so dark and the verses I write so clear," "deinde quod obscura de re tam lucida pango / carmina;" and V.11: "who by his skill brought life out of those temptestuous billows and that deep darkness, and settled it in such a calm and in light so clear," "quique per artem / fluctibus e tantis vitam tantisque tenebris / in tam tranquillo et tam clara luce locavit"). "even while maidens, Daughters of the Sun, were hastening / To escort me, after leaving the House of Night for the light," ö $\tau \varepsilon$

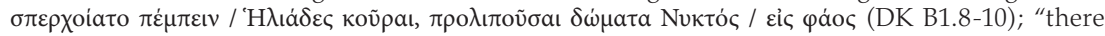

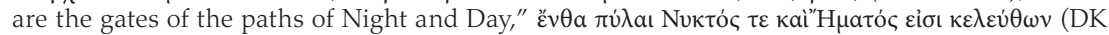
B1.11); Sextus Empiricus, Against the Mathematicians, VII.111-14 explains the fragment: "and the maidens that lead him on are the senses... and visual faculties he calls 'maidens, Daughters of the Sun, leaving the House of Night' and 'hastening into the light,' because it is impossible to

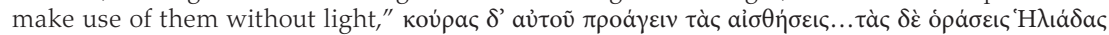

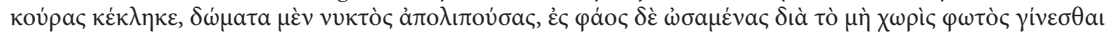

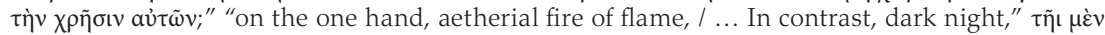

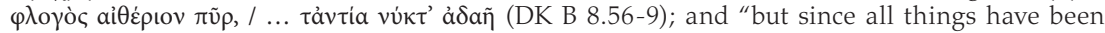

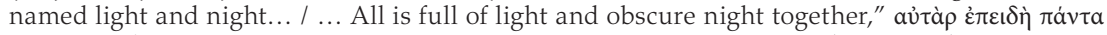

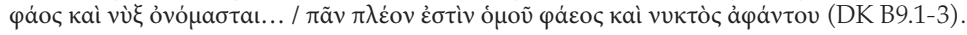


But avoidance is not the only reason. Although Sedley claims the Empedoclean influence upon the proem of DRN, he (1998: 21) continues that it is "only at this level of detail that the Epicureans, Lucretius included, are prepared to applaud the 'discoveries' of Empedocles." Therefore even with the example of Empedocles, any influence is understated.

And perhaps it is that Parmenides is not mentioned by very virtue of the extent of the influence which he wielded upon Epicureanism.

To my hypothesis then: Venus, and more so natura, are, and are meant to be recognised as, Parmenides' goddess.

And does this illuminate Parmenides at all? Why indeed is there a Goddess in Parmenides' poem? In much the same way as there is a Venus in $D R N$ : methodologically, opening with the mythical, a pillar of poetry, before expounding his doctrine. The Goddess is representative of nature, rather than being a religious, and this helps elucidate such a mysterious figure. And of the poet himself, his scientific ambitions, and his influence upon Epicureanism, have each been made much more explicit.

\section{BIBLIOGRAPHY}

Butler, H.E. 1989. Quintilian: Institutio Oratoria. Harvard University Press, Cambridge, Massachusetts; London, England.

Clay, D. 1983. Lucretius \& Epicurus. Cornell University Press: Ithaca and London.

Diels, H. 1965. Doxographi Graeci. Berolini: Apud Walter de Gruyter et socios.

Diels, H. \& Band, E. 1906. Die fragmente der vorsokratiker. Berlin: Weidmannsche Buchhandlung.

Diels, H. \& Kranz, W. 1951. Die Fragmente der Vorsokratiker. Weidmannsche Verlagsbuchhandlung.

Diels, H. \& Kranz, W. 1952. Die Fragmente der Vorsokratiker. Weidmannsche Verlagsbuchhandlung.

Furley, D. 1989. Cosmic problems: Essays on Greek and Roman philosophy of nature. Cambridge University Press: Cambridge, New York, New Rochelle, Melbourne, Sydney.

Gale, M. 1994. Myth and poetry in Lucretius. Cambridge University Press.

Gallop, D. 1984. Parmenides of Elea: Fragments. A text and translation with an introduction. University of Toronto Press: Toronto, Buffalo, London.

Godwin, J. 2004. Ancients in Action: Lucretius. Bristol Classical Press.

Hicks, R.D. 1925. Diogenes Laertius: Lives of Eminent Philosophers I. London: William Heinemann; New York: G.P. Putnam's Sons.

Hicks, R.D. 1991. Diogenes Laertius: Lives of Eminent Philosophers II. London: England; Cambridge, Massachusetts: Harvard University Press.

Lewis, C.T. 1996. An elementary Latin Dictionary. Oxford University Press.

Liddell, H.G. \& Scott, R. 1997. A Lexicon. Oxford: Clarendon Press. 
Minadeo, R. 1969. The lyre of Science: Form and Meaning in Lucretius' De Rerum Natura. Wayne State University Press, Detroit, Michigan.

Mourelatos, A.P.D. 1970. The route of Parmenides: A study of word, image, and argument in the fragments. New Haven and London: Yale University Press.

Murray, A.T. 1931. Homer: The Odyssey II. London: William Heinemann; New York: G.P. Putnam's Sons.

Murray, A.T. 1953. Homer: The Odyssey I. London: William Heinemann LTD; Cambridge, Massachusetts: Harvard University Press.

Patin, M. 1914. Études sur la poésie Latine. Paris : Libraire Hachette et Cie.

Rackham, H. 1961. Cicero: De Natura Deorum, Academica. London: William Heinemann LTD; Cambridge, Massachusetts: Harvard University Press.

Rouse, W.H.D. 1975. Lucretius: De rerum natura. Revised with new text, introduction, notes, and index by M.F.Smith. London: William Heinemann LTD; Cambridge, Massachusetts: Harvard University Press.

Rumpf, L. 2005. "Lukrez und Parmenides". Philologus 149.1: 78-95.

Sedley. D. 1998. Lucretius and the Transformation of Greek wisdom. Cambridge University Press.

Tarán, L. 1965. Parmenides: A Text with Translation, Commentary, and Critical Essays. Princeton, New Jersey: Princeton University Press.

Abstract. Recent scholarship on Lucretius' engagement with the tradition of philosophical poetry has tended to focus on the figure of Empedocles. Lucretius was undoubtedly familiar with his work, both eulogising and criticising the poet-philosopher by name in the first book of the De rerum natura; indeed, he was not alone. Philodemus in his On piety mentions an Epicurean polemic treatise, Against Empedocles, and Diogenes Laertius records that Epicurus himself wrote specifically about Empedocles. The inscription of Diogenes of Oenoanda mentions Empedocles too. While the influence of Empedocles upon Lucretius (Campbell, Furley), and especially upon the proem to the DRN (Sedley), has been suggested and duly accepted, that of another poet-philosopher bears further exploration. The influence of Parmenides upon Lucretius has been relatively neglected and, I argue, underestimated. Rumpf's 1995 article in Philologus, "Lukrez und Parmenides", claims Parmenides' influence upon the first two books of the DRN. Gale, on the other hand, has suggested that any influence is indirect. Although Lucretius does not mention Parmenides in the DRN, there are nevertheless striking intertextual echoes

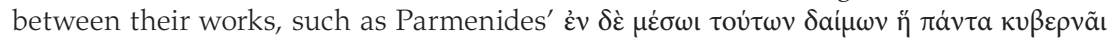
(F12) perhaps being answered by Lucretius' quae...rerum naturam sola gubernas (DRN 1.21) or solis cursus lunaeque meatus ... flectat natura gubernans (DRN 5.76-7). This paper will draw out some of these parallels, and go beyond Rumpf to advocate a Parmenidean influence upon the DRN as a whole, with respect to both Lucretius' mode of expression, and the very substance of the DRN and the Epicurean physics it imparts. It will thus demonstrate that there really is a Parmenides within Lucretius, and perhaps allow for further illumination of Parmenides, as well.

Keywords. Lucretius, Parmenides, poet-philosopher, influence, intertextuality. 